\title{
Urgensi Bimbingan, Konseling dan Tantangan Dakwah
}

\section{Rahmiyati}

UIN Antasari Banjarmasin

\begin{abstract}
Abtract
Every human being has hopes, desires, perceptions, emotions and other potentialities, they will bring people to trouble so that they feel life is always in trouble, inferior, helpless, sad, angry and in the end despair. The atmosphere will dim the power of human development in achieving happiness and development toward maturity. In other aspects of human beings as individual beings are also required as social beings. So humans must be able to interact, adapt to themselves and others and must be able to balance the balance between the two. But most humans have the limitations of bringing themselves to the perfection of life untik it is necessary guidance and counseling in human life. Especially for Muslims apart from the above mentioned descriptions of the problem which if faced unfinished will become more serious, that is live life out of the religious signs, then also will nest the inner illness that will eliminate the virtue of a Muslim. For that reason guidance and counseling its existence is very important in education and society in general. In detail the importance of guidance and counseling concerning aspects: psychological, socio-cultural, religious, educational and development of science and technology. In taking the life of every human being must be able to manage the psychological, social and cultural aspects must be able to face the development of science and technology, facing the temptations are misleading.
\end{abstract}

Keywords: urgency, guidance, counseling, da'wah.

\section{Pendahuluan}

Seiring perkembangan zaman, kompleksitas kehidupan dengan berbagai problem selalu meneylimut kehidupan manusia di muka bumi ini. Setiap manusia dibelahan dunia ini pasti memiliki poblem meski tinggal di tempat yang jauh dari hiruk pikuk kehidupan kota besar, begitu juga manusia yang tinggal ditempat atau di negara paling maju di dunia pasti juga akan mengalami problem.

Manusia sebagai makhluk yang unik selain mempunyai potensi kebaikan yang luar biasa, juga memiliki kelemahan dan keburukan yang juga luar biasa. Semakin manusia tidak mneyadari akan kekuatan kelemahannya maka semakin ia akan 
terjerumus kepada problem yang seakan tidak pernah berhenti.

Pada lingkup dunia pendidikan khususnya di sekolah para siswanya juga dikepung oleh masalah yang semakin beragam. Jalan pikiran mereka menjadi terbagi dengan masalah diluar sekolah dan di dalam sekolah. Suatu tindak layanan sekolah pada peserta didik dengan bimbingan konseling yang mengarahkan para para peserta didik untuk mengetahui bakat dan potensi dalam diri mereka.

Bimbingan konseling biasanya berbicara mengenai aspek psikologis, ini akan sangat penting jika ada banyak gangguan psikis pada peserta didik yang biasanya tertekan masalah dan tidak mampu menangkap pelajaran dengan baik. Bimbingan konseling juga sangat penting posisinya untuk membimbing siswa untuk mengerti dan memahami diri bahwa mereka adalah pribadi yang unik, setiap individu memiliki kelebihan tersendiri dan mampu bersaing.

Bimbingan dan konseling memiliki banyak fungsi dan kegunaan misalnya dapat mendetiksi secara dini masalah-masalah siswa yang berkaitan tentang masalah kelainan tingkah laku dan adaptasi. Sulitnya salah satu siswa untuk bergaul dan cenderung mengasingkan diri dari teman-temannya memiliki akar permasalahan yang biasanya beruntun.

Bimbingan dan konseling merupakan bagian yang tak terpisahkan dalam keseluruhan sistem pendidikan terutama di sekolah. Setiap pendidik sebenarnya memiliki peran sebaga pembibing, dan guru merupakan salah satu pendukung unsur pelaksana pendidikan yang mempunyai tanggung jawab sebagai pendukung pelaksana layanan bimbingan pendidikan di sekolah. Untuk itu guru dituntut untuk memiliki wawasan yang memadai terhadap konsep-konsep dasar bimbingan dan konseling di sekolah.

Dalam dunia dakwah bimbingan dan penyuluhan merupakan sarana efektif dalam membawa umat kepada jalan kebenaran sesui dengan fitrahnya sebagai hamba Allah Swt. Kesempurnaan perkembangan manusia akan tercapai jika individu bersangkutan dalam menjalani hidup sesuai dengan tuntunan Alquran dan Hadis, dan menjaga agar aspek rohani selalu bersih dan sehat, sebab penyakit rohanilah penyebab utama munculnya masalah individu. 


\section{Pembahasan}

Dunia pendidikan merupakan upaya membawa anak didik menuju jalan kebenaran dan fitrah manusia sebagai hamba Allah Swt. Para siswa tidak hanya memerlukan materi materi pelajaran sekolah, tetapi perlu mendapat bimbingan dan konselin, karena pada dasarnya setiap kehidupan pasti ada masalah. Memang sebagian orang bisa mengatasi masalahnya sendiri, tetapi tidak sedikit juga orang yang memerlukan bantuan orang lain untuk menyelesaikan masalah-masalah tersebut. Jadi apabila siswa tetap dibiarkan memiliki masalah tanpa dibantu, yang bersangkutan tidak akan bisa berkonsentrasi untuk memahami atau berfikir mengenai pelajarannya. Kalau ia masih punya beban fikiran yang lain. Maka dari itu bimbingan dan konseling disekolah sangatlah diperlukan.

Secara lebih terperinci kenapa bimbingan dan konseling sangat diperlukan? Jawaban tentu sangat banyak, pada kesempatan ini akan dikemukan beberpa faktor yang mengharuskan adanya bimbingan dan konseling yaitu:
1. Aspek Psikologis Manusia

Psikologis manusia sesuatu yang sangat sentral dalam perkembangannya, pada aspek ini sering tidak disadari dan difahami oleh manusiam sehingga akan menimbulkan masalah. Bimbingan dan Konseling memberikan pemahaman tentang potensi psikis dalam menentukan tingkah laku individu yang menjadi sasaran. Hal ini sangat penting karena bidang garapan bimbingan dan konseling adalah tingkah laku klien, yaitu tingkah laku yang perlu diubah atau dikembangkan untuk mengatasi masalah yang dihadapi.

Peserta didik sebagai individu yang dinamis dan berada dalam proses perkembangan, memiliki kebutuhan dan dinamika dalam interaksi dengan lingkungannya. Di samping itu, peserta didik senantiasa mengalami berbagai perubahan sikap dan tingkah lakunya. Proses perkembangan tidak selalu berlangsung secara linier (sesuai dengan arah yang diharapkan atau norma yang dijunjung tinggi), tetapi bersifat fluktuatif dan bahkan terjadi 
stagnasi atau diskontinuitas perkembangan.

Latar belakang dari segi psikologis menyangkut masalah perkembangan individu, perbedaan individu, kebutuhan individu penyesuaian diri serta masalah belajar. Berhasil tidaknya tugas perkembangan berikutnya ditentukan oleh perkembangan yang telah dilalui (Tohirin, 2007). Dengan demikian dalam rangka menuju kedewasaan yang sesuai dengan potensi individu sangat diperlukan bimbingan dan konseling.

2. Aspek Sosial Budaya

Setiap individu tidak akan bisa lepas dari sentuhan aspek sosial budaya, sehungga individu sebagai biopsikososiospiritual, yang artinya bahwa individu makhluk biologis, psikologis, sosial dan spiritual. Manusia sebagai makhluk sosial membutuhkan interaksi dan komunikasi dengan orang lain, butuh bantuan orang lain, secara singkat Paryitno \&Amti (2004), menyatakan bahwa semua orang memerlukan orang lain. Setiap anak sejak lahir tidak hanya mampu memenuhi tuntutan biologisnya, tetapi juga tuntutan budaya di mana individu itu tinggal, tuntutan budaya itu dilakukan agar segala dampak modrenisasi dapat di filter oleh individu tersebut secara otomatis, serta individu diharapkan dapat menyesuaikan tingkah lakunya sesuai dengan budaya yang sudah ada, agar dapat di terima dengan baik oleh lingkungan tersebut. Untuk mengembangkan semua kemampuan penyesuaian tersebut, sangat diperlukan sebuah bimbingan.

Terkait dengan layanan bimbingan dan konseling di Indonesia, Moh. Surya mengatakan tentang tren bimbingan dan konseling multikultural, bahwa bimbingan dan konseling dengan pendekatan multikultural sangat tepat untuk lingkungan berbudaya plural seperti Indonesia. Bimbingan dan konseling dilaksanakan dengan latar belakang berlandaskan semangat bhinneka tunggal ika, yaitu kesamaan di atas keragaman. Layanan bimbingan dan konseling hendaknya lebih berpangkal pada nilai-nilai budaya bangsa yang secara nyata mampu mewujudkan 
kehidupan yang harmoni dalam kondisi pluralistik.

3. Aspek Agama

Setiap manusia memiliki potensi untuk hidup beragama, dan hal itu dapat dikatakan sebagai kebutuhan yang tidak bisa ditinggalkan, untuk kebahagiaan hidup dunia akhirat. Manusia merupakan makhluk Tuhan yang pada dasarnya sama memiliki fitrah sebagai khalifah dan hamba-Nya. Sebagai makhluk baragama tidak semua manusia mampu menghadapi tantangan-tantangan hidup secara wajar dan benar sesuai ajaran agamanya. Sehubungan dengan itu bimbingan dan konseling sangat urgen bagi manusia. Berbagai dimensi kehidupan beragama memerlukan sekali bimbingan terutama pada tantangan dimensi spiritualitas individu, seperti: dekadensi moral, budaya hedonistik, dan penyakit hati. Bimbingan dalam hal ini diperuntukan agar setiap individu mampu memandang setiap tantangan kearah positif bukan malah terjerumus kearah negative, sehingga kehidupan dapat dijalani sesuai dengan kaidah-kaidah agama. Secara singkat Hikmawati (2015) bimbingan konseling membantu menguatkan komitmen beragama.

Dalam landasan agama, bimbingan dan konseling diperlukan penekanan pada 3 hal pokok yakni pada; keyakinan bahwa manusia dan alam semesta beserta isinya adalah mahluk/ciptaan dan milik Tuhan, sikap yang mendorong perkembangan dan perikehidupan manusia berjalan kearah dan sesuai dengan kaidah-kaidah agama, upaya yang memungkinkan berkembang dan dimanfaatkannya secara optimal suasana danperangkat budaya serta kemasyarakatan yang sesuai dengan kaidah-kaidah agama untuk membentuk perkembangan dan pemecahan masalah individu.

$$
\text { Landasan religius bimbingan }
$$
dan konseling pada dasarnya ingin menetapkan klien sebagai makhluk Tuhan dengan segenap kemuliaannya menjadi fokus sentral upaya bimbingan dan konseling. Pembahasan landasan religius ini, terkait dengan upaya mengintegrasikan nilai-nilai agama dalam proses bimbingan dan konseling (Hallen 2002). 
4. Aspek Pendidikan

Bimbingan dan konseling sebenarnya juga proses pendidikan terutama dalam hal membentuk perkembangan kedewasaan dan stabilotas individu. Pada sisi lain, bimbingan dan konseling diperlukan untuk mengembangkan pendidikan yang bersifat meninggi, meluas dan mendalam. Meninggi artinya membantu membimbing individu memilih jenjang pendidikan yang lebih tepat, karena semakin bertambahnya kesempatan dan kemungkinan untuk mencapai tingkat pendidikan yang lebih tinggi. Serta sangat diperlukan untuk membuat individu lebih mandiri dan berkembang secara optimal dalam berbagai bimbingan, seperti: bimbingan pribadi, sosial, belajar dan bimbingan karir melalui berbagai jenis kegiatan bimbingan, sehingga pendidikan dapat berjalan dengan lancar dengan adanya bimbingan dan konseling.

Arah meluas tampak dalam pembagian sekolah dalam berbagai jurusan khusus dan sekolah kejuruan. Hal ini menimbulkan kebutuhan akan bimbingan untuk memilih jurusan yang khusus dan memilih bidang studi yang tepat bagi setiap murid. Arah mendalam tampak dalam berkembangnya ruang lingkup dan keragaman disertai dengan pertumbuhan tingkat kerumitan dalam tiap bidang studi. Hal ini menimbulkan masalah bagi murid untuk mendalami tiap bidang studi dengan tekun. Perkembangan ke arah ini bersangkut paut pula dengan kemampuan dan sikap serta minat murid terhadap bidang studi tertentu. Ini semua menimbulkan akibat bahwa setiap murid memerlukan perhatian yang bersifat individual dan khusus. Dalam hal ini pula terasa sekali kebutuhan akan bimbingan di sekolah.

Untuk menuju tercapainya pribadi yang berkembang, maka kegiatan pendidikan hendaknya bersifat menyeluruh yang tidak hanya berupa kegiatan instruksional (pengajaran), akan tetapi meliputi kegiatan yang menjamin bahwa setiap anak didik secara pribadi mendapat layanan sehingga akhirnya dapat berkembang secara optimal. Kegiatan pendidikan yang diinginkan seperti tersebut di atas, adalah kegiatan pendidikan yang ditandai dengan pengadministrasian 
yang baik, kurikulum beserta proses belajar mengajar yang memadai, dan layanan pribadi kepada anak didik melalui bimbingan.

Dalam hubungan inilah bimbingan mempunyai peranan yang amat penting dalam pendidikan, yaitu membantu setiap pribadi anak didik agar berkembang secara optimal. Dengan demikian maka hasil pendidikan sesungguhnya akan tercermin pada pribadi anak didik yang berkembang baik secara akademik, psikologis, maupun sosial. Sehingga individu dapat memenuhi kebuthan internalnya dalam mengaktualisasikan dirinya (teori Maslow) secara mandiri sebagai manifestasi dari kedewasaannya (Nurhayati, 2011).

Ada tiga hal pokok yang menjadikan bimbingan sangat penting dan diperlukan dari segi pendidikan yaitu; pertama, hakikat pendidikan sebagai suatu usaha sadar dalam mengembangkan kepribadian. Hal ini mengandung implikasi bahwa proses pendidikan menuntut adanya pendekatan yang lebih luas dari pada sekedar pengajaran. Pendekatan yang dimaksud adalah pendekatan pribadi melalui layanan bimbingan dan konseling. Kedua, pendidikan senantiasa berkembang secara dinamis dan karenanya selalu terjadi perubahan perubahan dan penyesuaian dalam komponenkomponennya. Menghadapi perkembangan ini para siswa sebagai subjek didik memerlukan bantuan dalam penyesuaian diri melalui layanan bimbingan. Ketiga pada hakikatnya guru mempunyai peranan yang tidak hanya sebagai pengajar,tetapi lebih luas dari itu, yaitu sebagai pendidik. Sebagai pendidik, maka guru harus dapat menggunakan pendekatan pribadi dalam mendidik para siswanya. Pendekatan pribadi ini diwujudkan melalui layanan bimbingan.

5. Aspek Perkembangan IPTEK

Di era ini ilmu pengetahuan, informasi dan teknologi berkembang sangat pesat, oleh karena itu diperlukannya Bimbingan dan Konseling, agar individu dapat mengetahui dampak positif dan negatifnya dari perkembangan tersebut. Lewat Bimbingan dan Konseling, individu diarahkan kepada dampak positif dari IPTEK 
yang lebih ditujukan pada penerapan teknologi yang harus dimilliki dan dikuasai karena semakin kompleksnya jenis-jenis dan syarat pekerjaan serta persaingan antar individu.

Dengan teknologi jaringan tidak hanya mata kuliah atau bidang studi saja yang bisa memanfaatkan teknologi tinggi, melainkan hampir sebagian besar proses belajar mengajar termasuk BK (Bimbingan Konseling) atau Bimbingan Karier sudah bisa memanfaatkan teknologi.

Terkait sasaran layanan makin kompleks, diperlukan pelayanan BK yang profesional. Salah satu syarat pekerjaan profesional itu adanya komitmen menerapkan keahlian. Lembaga ataupun sekolah harus selalu menyiapkan guru BK yang adaptif dengan perubahan iptek sehingga teori yang dipelajari relevan dengan tugas BK.

Dengan teknologi khususnya jaringan komputer baik Intranet maupun Internet proses belajar mengajar, proses interaksi antara konselor dan klien bisa dilakukan kapan saja dan dimana saja tanpa dibatasi ruang dan waktu. Dengan demikian peran teknologi tinggi dalam dunia pendidikan khususnya Bimbingan dan Konseling sangat dibutuhkan untuk mendapatkan hasil yang sesuai dan maksimal.

\section{Tantangan Bimbingan dan}

\section{Konseling Islam Dalam Dakwah}

Tantangan dakwah Islami ke depan, sepertinya semakin kompleks dan rumit, seiring dengan perkembangan ilmu pengetahuan dan kemajuan zaman serta banyaknya isme yang menjamur dengan serta merta turut mempengaruhi cara berpikir umat.

Dalam konteks ini para juru dakwah juga dituntut mempunyai kemampuan dalam menyeru atau mengajak manusia kepada jalan Allah dengan menggunakan seni penyampaian dalam menghadapi umat dengan karakteristik dan keadaan yang berbedabeda. Dengan kata lain dapat dikatakan bahwa dakwah Islam tidak hanya sekedar menyampaikan, menyeru, dan mengajak ke jalan Allah hanya dengan kata-kata saja, perlu penjabaran secara lebih luas terhadap kegiatan dakwah saat ini dan masa mendatang.

Meskipun demikian kegiatan dakwah harus tetap kepada tema sentralnya yaitu Dienul Islam yang berpusat kepada tiga kemaslahatan yaitu 
:1) Menolak kerusakan demi memelihara; agama, jiwa akal, keturunan, kehormatan diri, dan harta. 2) Mendatangkan kemaslahatan, Alquran adalah pembawa kemaslahatan dan penagkal kerusakan. 3) Menerapkan akhlak mulia dan mentradisikan kebaikan.

Konsekwensi tersebut di atas berakibat pada bermunculannya konsepkonsep metode dan strategi dakwah yang dirancang lebih releabel dan fleksibel denga keadaan perkembangan zaman. tetapi pada intinya bersumber kepada tiga pendekatan dakwah yaitu dengan perkataan, perbuatan dan tulisan. Sebagai contoh upaya memperbaiki tarap hidup umat Islam merupakan salah satu strategi dakwah selain menggunakan ceramah agama.

Fenomena kehidupan yang begitu beragam dan rumit salah satu tantangan dakwah yang tidak bisa dianggap enteng. Dari beberapa kasus dapat diperhatikan bahwa seiring dengan gencarnya kegiatan dakwah dilaksanakan ternyata semakin gencar juga pelanggaran-pelanggaran terhadap norma agama.

Hal tersebut mengisyaratkan bahwa banyak permasalahan umat yang lebih bersifat situasional dan pribadi

yang tidak bisa dihadapi dengan strategi general, artinya permasalahan individu juga harus dihadapi sesuai dengan keadaan pribadi yang bersangkutan.

Berbicara tentang dakwah Islam erat sekali kaitannya dengan upaya membentuk/merubah prilaku seseorang atau umat kearah yang sesuai dengan kaidah-kaidah keIslaman, sedangkan prilaku adalah manifestasi dari hidup kejiwaan atau rohani seseorang. Dengan demikian individu akan melakukan perbuatan yang melanggar norma Agama jika keadaan jiwanya yang mengarahkan kepada hal tersebut. Tidak ada bedanya antara si kaya dan si misikin, masyarakat jelata atau pejabat.

Dengan banyaknya pelanggaran yang dilakukan oleh umat Islam berarti dakwah yang dilakukan selama ini dipandang kurang efektif, dan hal tersebut tentunya banyak vareabel yang mempengaruhinya, tetapi pada intinya adalah disebabkan oleh ketidak sabaran dalam menghadapi cobaan dan ketidak mampuan menahan berbagai bentuk godaan.

Konseling dapat digunakan
sebagai media dakwah yang
mengandung efektifitas tinggi.
Konseling merupakan upaya bantuan
kepada seseorang atau kelompok orang

Konseling dapat digunakan 
agar yang bersangkutan dapat memecahkan problemnya dengan berkonsultasi pada orang yang mempunyai keahlian dibidang itu. Individu yang keliru dan tidak menyadari untuk apa sebenarnya dia hidup dimuka bumi ini, dengan bantuan konseling Islam akan menyadari dan dengan ikhlas akan kembali kepada jalan yang diridhoi oleh Allah SWT.

Langkanya tempat konsultasi konseling di Kalimanantan Selatan, menyebabkan masyarakat bingung harus kemana dia dapat berkonsultasi. Ulama atau tokoh Agama merupakan salah satu tempat konsultasi bagi masyarakat. Disinilah moment yang tepat untuk memberikan anjuran dan pandangan yang rasional dan berbekas pada jiwa klien, tetapi inti dari kegiatan konsultasi tesebut adalah peningkatan keimanan.

Adz-Dzaky. (2001) berpendapat bahwa konseling dalam Islam adalah aktivitas memberikan bimbingan, pelajaran dan pedoman kepada individuyang meminta bantuan, bagaimana seharusnya seorang klien dapat mengembangkan potensi akal dan pikirannya, jiwanya, keimanan dan keyakinan serta dapat menanggulangi problematika hidup dan kehidupannya dengan baik dan benar secara mandiri yang berparadigma kepada Alquran dan Assunnah Rasulullah SAW.

Dari hasil penelitian menunjukan bahwa keimanan yang kuat akan dapat menyelesaikan berbagai problem kehidupan." Orang-orang yang beriman dan hati mereka menjadi tentram dengan mengingat Allah. Ingatlah, hanya dengan mengingat Allah-lah hati menjadi tenang. (Q.S. 13 :28).

\section{Simpulan}

Setiap manusia memiliki harapan, keinginan, persepsi, emosi dal potensi-potensi lainnya, semua itu akan membawa manusia kepada masalah sehingga yang bersangkutan merasa hidup selalu dalam kesulitan, rendah diri, tidak berdaya, sedih, marah-marah dan pada akhirnya putus asa. Suasana tersebut akan meredupkan daya berkembang manusia dalam mencapai kebahagian dan perkembangan menuju kedewasaan.

Pada aspek lain manusia sebagai makhluk individua juga diwajibkan sebagai makhluk sosial. Sehingga manusia harus mampu berinteraksi, menyesuaikan diri pada dirinya sendiri dan orang lain dan harus mampu nebjaga keseimbangan diantara keduanya. Tetapi kebanyak manusia memiliki keterbatasan membawa dirinya kepada kesempurnaan hidup 
untik itulah sangat diperlukan bimbingan dan konseling dalam kehidupan manusia.

Secara khusus bagi umat Islam selain dari uraian sebagaimana tersebut di atas masalah yang dhadapi jika tidak diselesaikan akan menjadi lebih serius, yaitu menjalani hidup keluar dari rambu-rambu agama, kemudian juga akan bersarang penyakit bathin yang akan menghilangkan amal kebajikan seorang muslim. Untuk itulah bimbingan dan konseling keberadaannya sangat penting dalam dunia pendidikan dan masyarakat secara umum.

Secara terperinci pentingnya bimbingan dan konseling menyangkut aspek: psikologis, sosial budaya,agama, pendidikan dan perkembangan ilmu pengetahuan dan teknologi. Dalam menempuh hidup setiap manusia harus mampu mengelola aspek psikis, sosial budayanya dan harus mampu menghadapi perkembangan ilmu pengetahuan dan teknologi, menghadapi godaan-godaan yang menyesatkan.

\section{Daftar Pustaka}

Adz-Dzaky. 2001. Psikoterapi dan Konseling Islam. Yogyakarta: Pajar Pustaka Baru.
Hallen. 2002. Bimbingan dan Konseling Islam, Jakarta: CiputatPrees.

Hikmawati. 2015. Bimbingan dan Konseling Perspektif Islam. Jakarta: RajaGrafindo Persada.

Nurhayati. 2011. Bimbingan, Konseling \& Psikoterapi Inovatif. Yogyakarta: Pustaka Pelajar.

Prayitno \& Amti. 2004. Dasar-dasar Bimbingan dan Konseling. Cet. 2. Jakarta: Rineka Cipta.

Tohirin. 2007. Bimbingan dan Konseling di Sekolah dan Madrasah (Berbasisi Integrasi). Jakarta: RajaGrafindo Persada. 